\title{
RESPONSE OF COWPEA TO FOLIAR SPRAY WITH SOME MICRONUTRIENTS (ZN, FE AND MN) AND IT'S REFLECT ON THE DRY SEED YIELD AND ITS COMPONENTS.
}

\author{
A. Y. Ismail and Hala H. Abou Elnour \\ Veg. Res. Dep. Hort. Res. Ins. Agric. Res. Center, Giza Egypt
}

Received: Jun. 12, 2016

Accepted: Jun. 27, 2016

\begin{abstract}
These field experiment werw carried out at Kaha Experimental Station, Qalubia Governorate during the two successive summer seasons of 2014 and 2015, to study the effect of foliar spray with some microelements, i.e. Fe, $\mathrm{Zn}$ and $\mathrm{Mn}$ at 150 and 200ppm for each on growth, seed yield and its components as well as on the chemical constituents of cowpea dry seeds (Vigna unguiculata L.) cv. Kafr El-Sheikh. The results indicated that, foliar spraying with mixture of some microelements i.e. Fe+ $\mathrm{Zn}+\mathrm{Mn}$ at 150ppm for each significantly increased growth, seed yield and its chemical constituents such as carbohydrates, protein \% and $\mathrm{Fe}, \mathrm{Zn}, \mathrm{Mn}$ in the dry seeds compared with the other treatments and the control. For that, it can be recommended that spraying cowpea plants with mixture of zinc, manganese and iron at the concentration of 150ppm from each gave the highest seed yield with best quality.
\end{abstract}

Key words: Cowpea, yield, quality, foliar application Fe, Mn and Zn.

\section{INTRODUCTION}

Legumes are considered the most important source of food after the grain crops and one of the main sources for protein, starch, oil, vitamin, minerals and energy for human. Currently, it can be a good alternative for animal protein and due to its nutrition values as well as an economic importance. Cowpea (Vigna unguiculata L.) is commonly referred as a poor man's meat, it can be planted it for seeds which containing 18-32 \% protein and nitrogen fixation ability. Cowpea seeds are a nutrition component in the human diet whereas, the protein in cowpea seeds is rich in lysine and tryptophan amino acids compared to cereals, (El -Hawary, 1999; Carvalho et al., 2012 and Katoch, 2013).

Fertilizer is a vital input in agriculture to boost the crop yields. Among the methods of fertilizer application, foliar nutrition is recognized as an important method of fertilization and more faster for absorption, since foliar nutrients usually penetrate the leaf cuticle or stomata and enters the cells facilitating easy and rapid utilization of nutrients. Most of the plant nutrients are absorbed through the leaves and absorption become rapidly and nearly complete. Moreover, foliar feeding practice would be more useful in early maturing crops, which could be combined with regular plant protection programs. If foliar nutrition is applied, it reduces the cost of cultivation which inturn reduces the amount of fertilizer thereby reducing the costs of crop production. Supplementary foliar fertilization during crop growth can improve the mineral status of plants and increase the crop yield, (Elayaraja and Angayarkanni; 2005 and Rajesh and Paulpandi, 2013).

Several investigators reported that, Zn, Fe and $\mathrm{Mn}$ had an important role in plant growth, yield and its quality. Moreover, its consider limited factor for many crops as mentioned by many researchers. Regarding to role of zinc, it was found that, Zinc $\left(\mathrm{Zn}^{2+}\right)$ is important element for plant growth through several aspects, which consider a component and activator for several enzymes such as dehydrogenase, proteinase, peptidase and phosphohydrases 
which act the main role in metabolism processes of carbohydrates, protein and phosphate. $\mathrm{Zn}$ is directly involved in biosynthesis of growth regulators such as IAA hormone which induces cell division and cell elongation and it is consider one of the auxins, that will be stored in the plant organs especially in the seeds. $\mathrm{Zn}$ is important for Carbon fixed thus reflected on photosynthesis processes, uptake nitrogen, nitrogen metabolism, protein quality, carbon anhydrate activity. Also, $\mathrm{Zn}$ deficient reduces the rate of protein accumulation in plant and seeds, zinc also stimulates plant resistance to dry and hot weather, (Marschner, 1998; Gurmani et al., 1988; Lincoln and Zeiger, 2002; Potarzycki and Grzebisz, 2009). Foliar application of Zinc at 0.5 and $0.4 \%$ increased pigeon pea and soybean seed yield respectively. Moreover, Concentrations of $\mathrm{Zn}, \mathrm{Fe}, \mathrm{P}$ and $\mathrm{K}$ increased in the plant leaves with increasing zinc concentration in foliar spray solution, (Osman et al., 2000; Masood and Mishra, 2001; Nasri and Khalatbari 2011).

Concerning to the role of iron in plants, it can said that, Iron $\left(\mathrm{Fe}^{3+}\right)$ is the third most limiting nutrient for plant growth and metabolism. Iron is involved in chlorophyll synthesis and it is essential for the maintenance of chloroplast structure and function as well as Fe plays a significant role in basic biological processes such as photosynthesis, respiration, nitrogen fixation, uptake mechanisms, protein and DNA synthesis. It is also an active factor of many enzymes that are necessary for plant hormone synthesis such as ethylene, lipoxygenase and carboxalic-oxidase, In addition, it serves as a component of many enzymes such as cytochromes of the electron transport chain and it is thus required for a wide range of biological functions. (Jahanara et al., 2013 and Gyana and Sahoo 2015).
Othman (2013) found that foliar application by $\mathrm{Fe}$ or $\mathrm{Zn}$ at $1 \%$ level showed significant effect on soybean protein content. In addition iron treatment has a greater effect on the nutrient uptake and protein percentage of seeds than other treatments.

Márquez-Quiroz1 et al., (2015) reported that the mineral seed contents and yields in cowpea plants are most affected by $\mathrm{Fe}$ fertilizer applications, they also reported that ferrous sulfate at $25 \mu \mathrm{M} \mathrm{L}^{-1}$ and iron chelate at $100 \mu \mathrm{M} \mathrm{L}^{-1}$ significantly improved the $\mathrm{Fe}$ concentration in cowpea, beans and increased the seed yield over the control.

As for manganese effect on several crops, many investigators indicated that, Manganese $\left(\mathrm{Mn}^{2+}\right)$ is an essential element for plants, intervening in several metabolic processes, mainly in photosynthesis its involvement in the water-splitting system of photosystem II (PSII), which provides electrons whereas, it is very necessary for photosynthetic electron transport. Moreover, Mn play as an enzyme antioxidant and cofactor of various enzymes in plants such as Mn-superoxide dismutase, Mn-catalase, pyruvate carboxylase and phosphoenolpyruvate carboxykinase. Manganese also plays a role in ATP synthesis, biosynthesis of fatty acids, lipids and proteins. In addition, Manganese is also essential for the biosynthesis of chlorophyll (through the activation of specific enzymes), aromatic amino acids (tyrosine), secondary products, like lignin and flavonoids. It is also participates in the biosynthetic pathway of isoprenoids and assimilation of nitrate. $\mathrm{Mn}$ is involved in metabolic processes such as respiration, photosynthesis, synthesis of aminoacids and hormone activation. (Goussias et al., 2002; Lidon et al., 2004; Ducic and Polle 2005; Millaleo1 et al., 2010)

Micronutrients have considerable significant effects, as limiting factors, on the productivity of cowpea. The importance of 
spraying microelements, $\mathrm{Fe}$ and $\mathrm{Zn}$ alone or in combination can be accounted by its essential role in respiration, their metabolism activation of the enzyme, photosynthesis, chloroplast formation, chlorophyll synthesis and natural hormone biosynthesis. Moreover, $\mathrm{Zn}+\mathrm{Fe}$ increased cowpea dry matter, total yield/plant and number of pods/plant. These elements play vital roles in $\mathrm{C}_{\mathrm{O} 2}$ flowing out, vitamin $\mathrm{A}$ improvement and resistant system activities. So, deficiency of these nutrients can markedly reduce crop's yield, and even can cause ceasing plant growth. Mostly, amounts of iron and zinc in soil are more than in the plant needs but cannot readily be absorbed by the plants, either it is fixed with other or by high level of soil pH. Thus, it is better to be added it as foliar application, as it is more effective than adding it's as soil fertilization, (Narimani et al., 2010; Abou El-khair et al., 2001).

The aim of this study is to investigate the effect of some micronutrients, i.e. $\mathrm{Zn}, \mathrm{Fe}$ and $\mathrm{Mn}$ as a foliar application as single application or as a mixture between them on cowpea seed yield and its quality.

\section{MATERIALS AND METHODS}

The present investigation was conducted at Kaha Research Farm, Qaliobia, Horticulture Research Institute, Agriculture Research Center during the two successive summer seasons of 2014 and 2015 to study the effect of foliar spraying with $\mathrm{Fe}, \mathrm{Zn}$ and $\mathrm{Mn}$ at 150 and 200ppm individual or mixture between them on growth, seed yield components, seeds quality and chemical constituents of cowpea seeds (Vigna unguiculata L.) cv. Kafr El-Sheikh. Sample of the soil at the depth of $50 \mathrm{~cm}$ from the soil surface was taken to determine the physical and chemical properties which determined according to (Black, 1965 and Page et al., 1982), were shown in Table (1).

This Experiment Included 9 Treatments as Follows:-

1- Control (tap water). The control plant sprayed with tap water.

2- Spraying with $\mathrm{Fe}$ at $150 \mathrm{ppm}$.

3- Spraying with $\mathrm{Fe}$ at $200 \mathrm{ppm}$.

4- Spraying with $\mathrm{Mn}$ at $150 \mathrm{ppm}$.

5- Spraying with Mn at $200 \mathrm{ppm}$.

6- Spraying with $\mathrm{Zn}$ at $150 \mathrm{ppm}$.

7- Spraying with $Z n$ at $200 \mathrm{ppm}$.

8- Spraying with Mixture of $\mathrm{Fe}+\mathrm{Mn}+$ $\mathrm{Zn}$ at $150 \mathrm{ppm}$.

9- Spraying with Mixture of $\mathrm{Fe}+\mathrm{Mn}+\mathrm{Zn}$ at $200 \mathrm{ppm}$.

The sources of microelements i.e., Fe, $\mathrm{Mn}$ and $\mathrm{Zn}$ were ferrous sulphate, manganese sulphate, zinc sulphate respectively. Seeds were sown in hills at 10 April during both seasons at $15 \mathrm{~cm}$ apart between plants on one side of the ridge. The studied treatments were arranged in a randomized complete block design with three replicates. The experimental unit area was $10.5 \mathrm{~m}^{2}$ which contained 5 rows with $3.5 \mathrm{~m}$ length and $60 \mathrm{~cm}$ width for each. One row was left between each two experimental plots to avoid the overlapping.

Table (1): Chemical and Physiological Analysis.

\begin{tabular}{|c|c|c|c|c|c|c|c|}
\hline \multirow[b]{2}{*}{ Seasons } & \multirow[b]{2}{*}{$\begin{array}{l}\text { Texture } \\
\text { class }\end{array}$} & \multirow[b]{2}{*}{ O.M.\% } & \multirow[b]{2}{*}{$\mathrm{pH}$} & \multirow{2}{*}{$\begin{array}{c}\text { E.C. } \\
\text { (m.mohs/(cm) }\end{array}$} & \multicolumn{3}{|c|}{ Available (ppm) } \\
\hline & & & & & $\mathrm{Fe}$ & $\mathrm{Zn}$ & Mn \\
\hline 2014 & clay & 2.01 & 8.39 & 0.32 & 6.9 & 1.2 & 3.4 \\
\hline 2015 & clay & 1.80 & 8.33 & 0.3 .6 & 7.0 & 1.3 & 2.1 \\
\hline
\end{tabular}


Plants were sprayed three times at 25, 45 and 65 days after sowing. Each experimental unit received 2 liter solutions of each concentration using spreading agent (Super film at $1 \mathrm{~cm} / \mathrm{L}$.) to improve adherence of the spray to the plant foliage for increasing absorption by the plants (Mortvedt et al., 1991). The untreated plants (check) were sprayed with tap water and spreading agent. The normal agricultural practices of cowpea production were followed according to the recommendations of Ministry of Agriculture.

\section{Data Recorded:-}

1- Vegetative growth characteristics:

Plant height $(\mathrm{cm})$, number of branches and fresh weight per plant were measured in five plants chosen randomly from each plot at flowering stages, (leaves, stems and branches) were dried at $70 \mathrm{C}^{\circ}$ till constant weight and then dry weight/plant was evaluated.

\section{2- Dry seed yield and its components:}

At harvesting time, a random samples of 5 plants from one row of each experimental plot were taken to evaluate dry seed yield and its components; number of seeds /pod, number of pods/plant, dry seed yield/plant, seed index (100-seed weight (g). Moreover, total dry seed yield per plot were evaluated as ( $\mathrm{kg} / \mathrm{plot})$ and then calculated as $\mathrm{kg}$ /feddan. Shell out\% of dry pods was calculated using the following equation:

$$
\text { Shell out } \%=\frac{\text { Weight of dry seeds }}{\text { Weight of dry pods }} \times 100
$$

\section{3- Chemical constituents of cowpea dry seeds as the folowing:}

Crude protein was calculated based on total $\mathrm{N}$ concentration according to (A.O.A.C, 1990). Total Carbohydrates were determined colorimetrically using the method described in A.O.A.C. Microelements; Iron, manganese and zinc were determined by atomic absorption spectrophotometer (FAAS Perkin Elmer HGA 4000 Programs) as described by Evenhuis and Dewaard (1980).

\section{4- Seed germination tests:}

Three random samples (100 seeds each) were used from each treatment for calculating the following records; germination percentage (\%), germination rate and sprout length $(\mathrm{cm})$. Germination rate was calculated according to the following equation;

Germination rate $=$

$(\mathrm{G} 1 \times \mathrm{N} 1)+(\mathrm{G} 2 \times \mathrm{N} 2)+\ldots \ldots \ldots(\mathrm{Gn} \times \mathrm{Nn})$

$$
\mathrm{G} 1+\mathrm{G} 2+\ldots \ldots \ldots \ldots \ldots \ldots \ldots \ldots \ldots
$$

Where: $G=$ Number of germinated seeds in certain day, $\mathrm{N}=$ Number of this certain day.

100 seeds were distributed on watered sheets of filtrated papers and incubated at $25 \mathrm{C}^{0}$ for 14 day. Sprout length was taken after germination beginning for 2 day intervals until finishing the incubation period (14 days).

\section{5- Statistical Analysis:}

The obtained data were subjected to statistical analysis as technique of randomized block design with three replicates in both growing seasons. All data were subjected to the analysis of variance according to (Gomez and Gomez, 1984), and L.S.D values were used for comparison.

\section{RESULTS AND DISCUSSIONS 1- Vegetative growth characters:}

Data in (Table 2) showed the effect of spraying cowpea plants with some microelements i.e. $\mathrm{Fe}, \mathrm{Zn}$ and $\mathrm{Mn}$ at 150 and $200 \mathrm{ppm}$ for on vegetative growth. It is obvious in such data that vegetative growth was promoted with all microelements used as compared to the control; plant height, No. of branches/plant, fresh and dry weight/plant were increased significantly with adding $\mathrm{Fe}$ 
at $150 \mathrm{ppm}$ individual and the most increment was obtained by adding the mixture of $\mathrm{Fe}+\mathrm{Mn}+\mathrm{Zn}$ at the rate of 150 ppm. This trend was clear in the both seasons.

These results may be due to the effect of these microelements on plant physiological processes, Fe which plays a prominent role in several vital processes in plant such as photosynthesis, respiration, nitrogen fixation, uptake mechanisms, protein and DNA synthesis consequently affecting plant growth (Jahanara et al., 2013 and Gyana and Sahoo 2015). $\mathrm{Zn}$ is important for $\mathrm{C}_{14}$ fixed in the primary photosynthetic process (Lincoln and Zeiger 2002). Zn there by it may increase photosynthetic efficiency which was reflected as stimulative effect on plant vegetative growth and also zinc is a one of the most important component in several kinds of enzymes such as dehydrogenase, proteinase, peptidase and phosphohydrases (metabolism of carbohydrates, protein and phosphate) and $\mathrm{Zn}$ is known to stimulate plant resistance to dry and hot weather (Marschner, 1998). Zn is also well known to be directly involved in biosynthesis of IAA hormone. On the other point manganese $(\mathrm{Mn})$ is involved in the evolution of $\mathrm{O}_{2}$ in photosynthesis. It is also a component of several enzyme systems. It has also important role function in chloroplast as a part of electron-transfer (oxidation-reduction) reactions and electron transport system. Moreover, Mn participates in the biosynthetic pathway of isoprenoids and assimilation of nitrate (Ducic and Polle 2005; Millaleo1 et al., 2010). The obtained results are in agreement with those reported by (Gad and Kandil, 2013; Eisa and Ali, 2014 on cowpea and El-Mansi et al., 2005 on pea) they illustrated that, spraying plants with mixtures of ( $\mathrm{Fe}, \mathrm{Zn}, \mathrm{Mn}, \mathrm{Mo}$ and $\mathrm{B})$ at different concentrations increased vegetative growth characters compared with the control. Nevertheless, Faizus and Rahman, 2012 and Inayat et al., 2014 showed that a significant difference was observed in common bean (Phaseolus vulgaris L.) vegetate growth when plants were sprayed it with zn alone. Moreover, the increments in plant height and No. of branches/plant were recorded with foliar spray by mixture form $(B+M o+Z n)$.

Table (2): Vegetative growth characteristics of cowpea as affected by foliar application with some microelements in the seasons of 2014 and 2015.

\begin{tabular}{|l|c|c|c|c|c|c|c|c|}
\hline \multirow{2}{*}{ Treatments } & \multicolumn{4}{|c|}{ 1st season } & \multicolumn{4}{c|}{ 2nd season } \\
\cline { 2 - 10 } & $\begin{array}{c}\text { Plant } \\
\text { height } \\
(\mathrm{cm})\end{array}$ & $\begin{array}{c}\text { No. of } \\
\text { branches } \\
\text { / plant }\end{array}$ & $\begin{array}{c}\text { Fresh } \\
\text { weight } \\
\text { (g/plant }\end{array}$ & $\begin{array}{c}\text { Dry } \\
\text { weight } \\
(\mathrm{g} / \text { plant }\end{array}$ & $\begin{array}{c}\text { Plant } \\
\text { height } \\
(\mathrm{cm})\end{array}$ & $\begin{array}{c}\text { No. of } \\
\text { branches } \\
\text { / plant }\end{array}$ & $\begin{array}{c}\text { Fresh } \\
\text { weight } \\
\text { (g/plant }\end{array}$ & $\begin{array}{c}\text { Dry } \\
\text { weight } \\
\text { (g/plant }\end{array}$ \\
\hline Control & 56.50 & 5.50 & 149.24 & 26.30 & 63.30 & 7.70 & 153.60 & 27.04 \\
\hline Fe at 150ppm & 75.00 & 7.00 & 314.90 & 40.90 & 82.70 & 8.00 & 320.00 & 42.39 \\
\hline Fe at 200ppm & 73.20 & 7.00 & 264.70 & 31.30 & 81.28 & 7.60 & 308.12 & 33.15 \\
\hline Mn at 150ppm & 66.10 & 6.50 & 236.90 & 29.60 & 70.00 & 7.00 & 250.52 & 32.20 \\
\hline Mn at 200ppm & 63.40 & 6.20 & 197.70 & 28.70 & 65.30 & 6.10 & 220.86 & 29.61 \\
\hline Zn at 150ppm & 67.60 & 6.60 & 297.60 & 30.90 & 69.30 & 7.20 & 313.00 & 32.31 \\
\hline Zn at 200ppm & 64.20 & 6.50 & 254.80 & 31.20 & 65.40 & 7.20 & 293.14 & 32.00 \\
\hline Fe + Mn + Zn at 150ppm & 78.63 & 7.20 & 350.55 & 46.50 & 84.05 & 8.00 & 390.44 & 48.22 \\
\hline Fe $+\mathrm{Mn}+\mathrm{Zn}$ at 200ppm & 75.50 & 7.00 & 310.70 & 42.40 & 81.82 & 7.81 & 324.17 & 44.76 \\
\hline LSD & 5.57 & 0.86 & 38.24 & 6.92 & 4.43 & 0.63 & 32.56 & 6.34 \\
\hline
\end{tabular}




\section{2- Dry seed yield and its components:}

Data in (Table 3) illustrated the effect of spraying cowpea plants with some microelements; i.e. Fe, $\mathrm{Zn}$, and $\mathrm{Mn}$ at 150 or 200ppm on seed yield and its components i.e. number of seeds/pod, umber of pods/plant, seeds weight/pod, seed index, shell out and seed yield/plant as well as seed yield/fed. It can be concluded that, yield and its components were significantly increased by spraying plants with $\mathrm{Zn}$ at 150 ppm individually or spraying the mixture of the three microelements i.e. Fe, $\mathrm{Zn}$ and $\mathrm{Mn}$ used in this study at $150 \mathrm{ppm}$ compared with the control (tap water) or the other tested treatments, in other meaning it can said that, the favorable treatments that produced the superior seed yield either per plant or per feddan were spraying the cowpea plants with the mixture of $\mathrm{Fe}+\mathrm{Mn}+\mathrm{Zn}$ at 150ppm then, the treatment of foliar spray with $\mathrm{zn}$ alone at 150ppm. This increment was clear during the two both seasons. The increment in total seed yield may be directly due to the increment in vegetative growth (Table 2). Also these increases might be due to the favorable role of the tested micronutrients in pigments formation, photosynthesis activation and carbohydrates assimilation consequently reflected on the seed production (Bhuiyan et al., 2008). The results are in conformity with those obtained by (Gad and Kandil, 2013; Eisa and Ali 2014 on cow pea, El-Mansi et al., 2005 and ElSayed et al., 2012 on pea) they illustrated that spraying the plants with mixtures of $(\mathrm{Fe}$, $\mathrm{Zn}, \mathrm{Mn}, \quad \mathrm{Mo}$ and $\mathrm{B})$ at different concentrations gave the highest 1000 seed wt. and increased dry seeds/plant as well as/fed compared with the control. In some studies which carried out by (Faizus and Rahman, 2012; Inayat et al., 2014 and Sedighe and kavoos, 2015) on common bean, the results indicated that foliar application which include zinc alone or combined with $B$ and Mo recorded the maximum number of pods/plant, seeds/pods, seed index and dry seed yield/fed in the both seasons.

Table (3): Dry seed yield and its components of cowpea as affected by foliar application with some microelements in the seasons of 2014 and 2015.

\begin{tabular}{|c|c|c|c|c|c|c|c|c|c|c|c|c|}
\hline \multirow[b]{2}{*}{ Treatments } & \multicolumn{6}{|c|}{ 1st season } & \multicolumn{6}{|c|}{ 2nd season } \\
\hline & $\begin{array}{c}\text { No. } \\
\text { of } \\
\text { pods/ } \\
\text { plant }\end{array}$ & $\begin{array}{c}\text { No. } \\
\text { of } \\
\text { seeds/ } \\
\text { pod }\end{array}$ & $\begin{array}{l}\text { Seed } \\
\text { index }\end{array}$ & $\begin{array}{l}\text { Seed wt } \\
(\mathrm{g} / \mathrm{pod})\end{array}$ & $\begin{array}{c}\text { Dry } \\
\text { seed } \\
\text { wt. } \\
\text { (g/plant }\end{array}$ & $\begin{array}{c}\text { Dry } \\
\text { seed } \\
\text { yield } \\
(\mathrm{kg} / \mathrm{fed})\end{array}$ & $\begin{array}{c}\text { No. of } \\
\text { pods/ } \\
\text { plant }\end{array}$ & $\begin{array}{c}\text { No. of } \\
\text { seeds/ } \\
\text { pod }\end{array}$ & $\begin{array}{l}\text { Seed } \\
\text { index }\end{array}$ & $\begin{array}{c}\text { Seed } \\
\text { wt. } \\
\text { (g/pod) }\end{array}$ & $\begin{array}{c}\text { Dry } \\
\text { seed } \\
\text { wt. } \\
\text { (g/plant) }\end{array}$ & $\begin{array}{c}\text { Dry } \\
\text { seed } \\
\text { yield } \\
(\mathrm{kg} / \mathrm{fed})\end{array}$ \\
\hline Control & 15.75 & 7.72 & 16.66 & 2.38 & 21.51 & 732.93 & 16.09 & 8.70 & 20.49 & 2.68 & 21.92 & 780.60 \\
\hline Fe at 150ppm & 27.50 & 8.90 & 17.97 & 2.75 & 22.82 & 758.77 & 27.65 & 9.57 & 19.04 & 3.05 & 23.68 & 820.97 \\
\hline Fe at 200ppm & 25.78 & 8.65 & 17.28 & 2.49 & 22.17 & 749.60 & 26.22 & 9.41 & 18.08 & 2.77 & 22.79 & 793.73 \\
\hline Mn at 150ppm & 28.13 & 10.30 & 25.20 & 2.82 & 24.09 & 791.67 & 28.77 & 10.37 & 25.71 & 3.14 & 24.73 & 837.00 \\
\hline Mn at 200ppm & 27.83 & 9.10 & 18.08 & 2.62 & 23.26 & 775.30 & 28.04 & 10.07 & 20.25 & 2.85 & 23.94 & 798.33 \\
\hline $\mathrm{Zn}$ at $150 \mathrm{ppm}$ & 36.25 & 10.78 & 27.31 & 3.28 & 26.41 & 880.60 & 37.09 & 11.16 & 30.14 & 3.50 & 26.84 & 931.43 \\
\hline Zn at 200ppm & 28.19 & 9.70 & 26.65 & 3.11 & 23.75 & 803.73 & 29.09 & 10.72 & 26.91 & 3.19 & 24.25 & 864.07 \\
\hline $\begin{array}{l}\mathrm{Fe}+\mathrm{Mn}+\mathrm{Zn} \mathrm{a} \\
\text { 150ppm }\end{array}$ & 42.00 & 12.40 & 30.11 & 3.53 & 29.16 & 893.60 & 44.07 & 12.94 & 32.33 & 3.95 & 29.88 & 951.07 \\
\hline $\begin{array}{l}\mathrm{Fe}+\mathrm{Mn}+\mathrm{Zn} \mathrm{a} \\
200 p p m\end{array}$ & 29.92 & 10.88 & 28.71 & 3.37 & 25.95 & 841.13 & 32.00 & 11.60 & 30.83 & 3.70 & 27.17 & 915.83 \\
\hline LSD & 4.92 & 1.15 & 4.09 & 0.63 & 3.13 & 107.30 & 4.97 & 1.08 & 3.68 & 0.71 & 2.72 & 100.19 \\
\hline
\end{tabular}




\section{3- Chemical constituents in cowpea dry seeds:}

Data in Table (4) clearly indicated that spraying some microelements, i.e. Fe, Zn, and $\mathrm{Mn}$ greatly improved the chemical composition. i.e., protein, carbohydrates, Fe, $\mathrm{Zn}$ and $\mathrm{Mn}$ percentage in cowpea dry seeds as a reflection of spraying the plants with all tested microelements compared with the control in both seasons. The best value for protein, carbohydrates and Fe content in dry seeds were obtained by spraying the plants with $\mathrm{Fe}$ at $150 \mathrm{ppm}$ individually or mixture of all microelements (Fe, $\mathrm{Zn}$ and $\mathrm{Mn}$ ) at 150 ppm compared with the control (tap water) or with the other tested treatments. Whereas, the best results for $\mathrm{Zn} \%$ was indicated from using $\mathrm{Zn}$ at $150 \mathrm{ppm}$ individually or spraying the mixture of all microelements ( $\mathrm{Fe}, \mathrm{Zn}$ and $\mathrm{Mn}$ ) at $150 \mathrm{ppm}$. On the other hand, the highest values of $\mathrm{Mn}$ was obtained by foliar spray with $\mathrm{Mn}$ at 150 ppm individually or spraying the mixture of all microelements ( $\mathrm{Fe}, \mathrm{Zn}$ and $\mathrm{Mn}$ ) at 150 ppm. All the above mentioned concentrations gave significant increase than the control. The positive effect of micronutrients on dry seeds chemical contents may be due to their involvement in one or more of important biological functions such as synthesis of chlorophyll, electron transport system, oxidation-reduction reactions, protein synthesis and degradation, (Dwivedi, 1991; Nofal et al., 1998 and Radwan and Tawfik, 2004). Moreover, Zinc $(\mathrm{Zn})$ is necessary for plant growth as an activator of several enzymes and it is directly involved in the biosynthesis of growth regulators such as auxin, which promotes production of more plant cells and biomass that will be stored in the plant organs especially in seeds (Marschner, 1995). These results are in harmony with those reported by (Mohammad et al., 2011 on Phaseolous Vulgaris and Othman 2013 on cowpea), they reported that foliar application by $\mathrm{Fe}$ or $\mathrm{Zn}$ at $1 \%$ level on nutrient concentration produced the high values from contents of protein and carbohydrate in the seed. They added also that, iron treatment has a greater effect on the nutrient uptake and protein percentage in seeds than the other treatments. Also, Eisa and Ali (2014) working on cowpea and mentioned that $\mathrm{Fe}, \mathrm{Zn}, \mathrm{Mn}, \mathrm{Mo}$ and $\mathrm{B}$ contents in seeds were increased with spraying the plants by all the concentrations of $\mathrm{Fe}, \mathrm{Zn}, \mathrm{Mn}$, and $\mathrm{B}$ as compared to the control.

\section{4- Seed germination tests:}

Data represented in Table (5) showed that, it obtained significant increases in seed germination tests, i. e. percentage of germination, germination rate and sprout length were obtained by spraying cowpea plants with the all tested treatments compared with the control (tap water). Whereas, the greatest values were obtained by spraying cowpea plants with $\mathrm{Fe}$ at 150 ppm individual or by mixing $\mathrm{Fe}, \mathrm{Mn}$ and $\mathrm{Zn}$ at 150 or 200 ppm compared with the other treatments or the control. This trend was true in the both seasons. 
Table (4): Protein, Carbohydrates, Fe, $\mathrm{Mn}$ and $\mathrm{Zn}$ percentages in cowpea seeds as affected by foliar application with some microelements in the both seasons of 2014 and 2015.

\begin{tabular}{|l|c|c|c|c|c|c|c|c|c|c|}
\hline \multirow{2}{*}{ Treatments } & \multicolumn{4}{|c|}{ 1st season } & \multicolumn{5}{c|}{ 2nd season } \\
\cline { 2 - 13 } & Protien & $\begin{array}{c}\text { Charboh- } \\
\text { ydrate }\end{array}$ & Fe & Mn & Zn & Protien & $\begin{array}{c}\text { Charboh- } \\
\text { ydrate }\end{array}$ & Fe & Mn & Zn \\
\hline Control & 15.17 & 24.69 & 6.06 & 3.38 & 3.87 & 15.63 & 25.12 & 6.12 & 3.42 & 4.12 \\
\hline Fe at 150ppm & 22.49 & 34.30 & 6.09 & 3.45 & 4.06 & 22.84 & 34.89 & 6.12 & 3.47 & 4.10 \\
\hline Fe at 200ppm & 21.16 & 33.29 & 6.10 & 3.47 & 4.00 & 21.67 & 33.61 & 6.14 & 3.48 & 4.08 \\
\hline Mn at 150ppm & 16.59 & 26.95 & 6.15 & 3.76 & 4.10 & 17.00 & 27.33 & 6.18 & 3.45 & 4.71 \\
\hline Mn at 200ppm & 15.79 & 27.27 & 6.13 & 3.42 & 4.54 & 16.23 & 27.78 & 6.16 & 3.42 & 4.58 \\
\hline Zn at 150ppm & 18.27 & 30.73 & 6.19 & 3.42 & 4.60 & 18.77 & 31.16 & 6.23 & 3.73 & 4.32 \\
\hline Zn at 200ppm & 18.05 & 28.19 & 6.16 & 3.68 & 4.02 & 18.53 & 28.86 & 6.17 & 3.72 & 4.25 \\
\hline Fe + Mn +Zn at 150ppm & 23.20 & 36.17 & 6.52 & 4.23 & 4.82 & 23.89 & 36.85 & 6.54 & 4.46 & 4.86 \\
\hline Fe + Mn +Zn at 200ppm & 19.48 & 33.90 & 6.40 & 4.04 & 4.64 & 19.73 & 34.29 & 6.45 & 4.14 & 4.66 \\
\hline LSD & 1.00 & 0.69 & 0.16 & 0.30 & 0.56 & 0.91 & 0.56 & 0.14 & 0.25 & 0.52 \\
\hline
\end{tabular}

Table (5): Germination percentage (\%), germination rate and sprout length of cowpea seeds as affected by foliar application with some microelements in the both seasons of 2014 and 2015.

\begin{tabular}{|l|c|c|c|c|c|c|}
\hline \multirow{2}{*}{ Treatments } & \multicolumn{3}{|c|}{ 1st season } & \multicolumn{3}{c|}{ 2nd season } \\
\cline { 2 - 7 } & $\begin{array}{c}\text { Germination } \\
(\%)\end{array}$ & $\begin{array}{c}\text { Germination } \\
\text { rate (day) }\end{array}$ & $\begin{array}{c}\text { Seedling } \\
\text { length } \\
(\mathrm{cm})\end{array}$ & $\begin{array}{c}\text { Germination } \\
\%\end{array}$ & $\begin{array}{c}\text { Germination } \\
\text { rate (day) }\end{array}$ & $\begin{array}{c}\text { Seedling } \\
\text { length } \\
(\mathrm{cm})\end{array}$ \\
\hline Control & 82.67 & 1.86 & 29.83 & 89.00 & 1.94 & 31.66 \\
\hline Fe at 150ppm & 93.33 & 2.04 & 32.90 & 94.00 & 1.94 & 32.27 \\
\hline Fe at 200ppm & 97.33 & 2.100 & 35.80 & 98.00 & 2.12 & 35.07 \\
\hline Mn at 150ppm & 94.67 & 2.17 & 31.72 & 96.00 & 2.16 & 34.40 \\
\hline Mn at 200ppm & 88.00 & 2.08 & 32.55 & 88.67 & 2.02 & 32.90 \\
\hline Zn at 150ppm & 92.00 & 1.94 & 31.67 & 92.33 & 2.080 & 32.13 \\
\hline Zn at 200ppm & 92.00 & 2.16 & 34.80 & 93.33 & 1.940 & 33.37 \\
\hline Fe + Mn +Zn at 150ppm & 98.00 & 1.43 & 37.63 & 98.67 & 1.487 & 35.30 \\
\hline Fe + Mn +Zn at 200ppm & 95.33 & 1.68 & 37.70 & 96.00 & 1.700 & 34.27 \\
\hline LSD & 6.51 & 3.50 & 0.22 & 6.26 & 5.53 & 0.08 \\
\hline
\end{tabular}




\section{CONCLUSION}

It can be concluded that foliar spraying cowpea plants with some micronutrients, i.e. mixture of $(\mathrm{Fe}+\mathrm{Mn}+\mathrm{Zn})$ at $150 \mathrm{ppm}$ enhanced the plant height, number of branches/plant, number of pods/plant, number of seeds/pod as well as seed weight/plant yield as well as total seed yield per fed. Thus, it can be recommend by using foliar application with some micronutrients; $(\mathrm{Fe}+\mathrm{Mn}+\mathrm{Zn})$ at 150ppm to obtain the highest cowpea seed yield with best quality.

\section{REFERENCES}

Abou El-khair, E. E., I. A. S. Al-Esaily and N. M. El-Sarkassy (2001). Physiological response of garlic plant grown in sandy soil to foliar spray with iron, zinc and manganese either individual or in mixture form. Minufiya J. Agric. Res., 36(2): 409426.

A. O. A. C. (1990). Official Method of Analysis $10^{\text {th }}$ Association of Official Analytical Chemists. Inc. USA.Horneck, D. A. and D.

Bhuiyan, M. M. H., M. M. Rahman, F. Afroze, G. N. C. Sutradhar and M. S. I. Bhutyan (2008). Effect of Response of phosphorus, molybdenum and rhizobium inoculation on growth and nodulation on mung bean. J. Soil and Nature. 2(2):2530.

Black, C. A. (1965). Methods of soil analysis part I- physical and mineralogical properties. A. S. A. Madison Wise., USA.

Carvalho, A. F. U., N. M. de Sousa, D. F. Farias, L. C. B. da Rocha-Bezerra and R. M. P. da Silva (2012). Nutritional ranking of 30 brazilian genotypes of cowpeas including determination of antioxidant capacity and vitamins. J. Food Compos Anal: 81-88.

Ducic, T and A. Polle (2005). Transport and detoxification of manganese and copper in plants. Braz. J. Plant Physiol. :103112.
Dwivedi, G. K. (1991). Mode of application of micronutrients to sweet potato in acid soil of Garhwal Himalaya. Indian J. Hort. 48: 258 - 263.

Eisa, G. S. A and T. B. Ali (2014). Impact spraying of some microelements on growth, yield, nitrogenase activity and anatomical features of cowpea plants .World J. of Agric. Sci. 10 (2):57-67

Elayaraja, D. and A. Angayarkanni (2005). Effect of foliar nutrition on the nodulation and yield of rice fallow blackgram. J. Andhra Agric., 52: 602-604

El-Hawary, N. A. (1999). Effect of a new macro-micronutrients formulation on the yield production of some field and vegetable crops. J. Agric. Sci. Mansoura Univ. 24: 5175-5186.

El-Mansi, A. A., H. M. Arisha, A. I. ELKassas and E. M. E. Nour (2005). Effect of iron, molybdenum and boron and their spray methods on pea plants under sandy soil conditions 1 . Morphological characters, photosynthetic pigments, dry weight and activity. The 6th Arabian Conference for Horticulture, Ismailia, Egypt. pp: 325-339.

El-Sayed, H. E. A., E. A. Amen, A. H. ElMorsy and M. H. Tolba (2012). Effects of foliar spraying with microelements and different fertilizer sources on quality and yield of Pisum sativum, L. plant .International Research Journal of Agric. Sci. and Soil Sci. 2:017-024.

Evenhuis, B. and T. W. Dewaard (1980). Principles and Practices in Plant Analysis. FAO Soils Bull. 38:152-165.

Faizus, and S. Rahman (2012). Effects of zinc and nitrogen fertilizer and their application method on yield and yield components of Phaseolus vulgaris $\mathrm{L}$. http://dx.doi.org/10.4236/as.2012 3 (1):913.

Gad, N. and H. Kandil (2013). Evaluate the effect of molybdenum and different nitrogen levels on cowpea Vigna 
anguiculata. J. Apple. Sci. Res, 9(3):1490-1497.

Gomez, K. A. and A. A. Gomez (1984). Statistical procedures for the agricultural researches. John Wiley and Son, Inc. New York.

Goussias, C., A. Boussac and W. Rutherford (2002). Photosystem II and photosynthetic oxidation of water: an overview. Phil. Trans. R. Soc. Lond. B 357, 1369-1381.

Gurmani, A. H., B. H. Shahani, S. Khan and M. A. Khan (1988). Effect of various micronutrients $(\mathrm{Zn}, \mathrm{Cu}, \mathrm{Fe}, \mathrm{Mn})$ on the yield of paddy. Sarhad J. and Agric, 4: 515-520.

Gyana, R. R and S. Sahoo (2015). Role of iron in plant growth and metabolism. Ravi.Agric. Sci. (3):1-24.

Inayat, U., A. R. Afzal, I. Zafar, I. F. S. Salma, S. M. Shafiu and M. Afzal (2014). Response of common bean Phaseolus vulgaris to basal applied and foliar feeding of different nutrients application. J. Agric. \& Environ. Sci., 14(9):851-854.

Jahanara, F. S. M. Sadeghi and M. Ashouri (2013). Effect of nano-iron (Fe) fertilization and rhizobium leguminosarum on the qualitative and quantitative traits of Phaseolus vulgaris L. genotypes. Intl. J. Agri. Crop Sci. 5:572-578.

Katoch, R. (2013). Nutritional potential of rice bean Vigna umbellata an underutilized legume. J. Food Sci.:8-16.

Lidon, F. C., M. Barreiro and J. Ramalho (2004). Manganese accumulation in rice: in implications for photosynthetic functioning. J. Plant Soil. 1611:235-44.

Lincoln, T and E. Zeiger (2002). Plant physiology, publisher, sinauer associates; 3 edition. $\mathrm{Pb} .690$.

Márquez-Quiroz, C., E. C. Lázaro, R. O. Osorio and E. S. Chávez (2015). Bofortification of cowpea beans with iron: iron's influence on mineral content and yield. J. Soil Sci. Plant Nutr. 15(4):839847

Marschner, H (1995). Mineral nutrition of higher plants. 2nd edition, academic press, London, $645 \mathrm{pp}$.

Marschner, H (1998). Mineral nutrition of higher plants. 2nd ed. academic press, Harcourt Brace and Company, Publisher London, San Diego, New York Boston, Sydney, Tokyo, Toronto, 864 pp.

Masood Ali and J. P. Mishra (2001). Effect of foliar nutrition of boron and molybdenum on chickpea. Indian, J. Pulses Res., 14(1):41-43.

Millaleol, R., M. Reyes-Díaz, A .G. Ivanov, M. L. Mora and M. Alberdi (2010). Manganese as essential and toxic element for plants, transport, accumulation and resistance mechanisms. J. Soil Sci. Plant Nutr. 10:476-494

Mohammad, N., M. Khalatbari and H. A. Farahani (2011). Zn foliar application Influence on quality and quantity features in Phaseolous Vulgaris under different levels of $\mathrm{N}$ and $\mathrm{K}$ Fertilizers. Adv. Environ. Biol. 5:839-846.

Mortvedt, J. J., F. R. Cox, L. M. Shuman and R. M. Welch (1991). Micronutrients in agriculture, 2nd ed. Published by Soil Soc. Amer. Inc. Madison, Wisconsin, USA, $760 \mathrm{pp}$.

Narimani, H., M. M. Rahimi, A. Ahmadikhan and B. Vaezi (2010). Study on the effects of foliar spray of micronutrient on yield and yield components of durum wheat. Appl. Sci. Res. 2:168-176.

Nasri, M. and M. Khalatbari (2011). Effect of different nitrogen, potassium and zinc fertilizer on quantities and qualities characteristic of green beans. Ecophysiological Crop Journal. 3(1): 82-93.

Nofal, O. A., M. F. El-Masri and A. A. ElSaed (1998). Response of some potato cultivars growth on alluvial soil to micronutrients foliar spray. J. Agric. Sci. Mansoura Univ. 23 (8):4121-4133 
Othman, H. S. (2013). Effect of foliar fertilization of $\mathrm{Fe}, \mathrm{B}$ and $\mathrm{Zn}$ on nutrient concentration and seed protein of Cowpea "Vigna Unguiculata. J. Agric. Veterin. Sci. 6(3):42-46.

Osman, A. S., Y. M .Y. Abido and S. M. M. Allam (2000). Response of soybean to phosphorus and zinc fertilizer under irrigation regime. Ann. Agric. Sci. 45(1): 229-238.

Page, A. L., R. H. Miller and D. R. Keeney (1982). Methods of soil analysis. Part (II) chemical and microbiological properties. A. S. A. Madison Wisc., USA.

Potarzycki, J. and W. Grzebisz (2009). Effect of zinc foliar application on grain yield of maize and its yielding components. Plant Soil Environ, 55(12):519-527.

Radwan, E. A. and A. A. Tawfik (2004). Effect of sulphur, manganese and zinc on growth, yield and quality of potato (Solanum tuberoium, L) J. Agric. Sci. Mansoura Univ. 29 (3):1423-1431.

Rajesh, N. and V. K. Paulpandi (2013). Review of foliar nutrition in red-gram enhancing the growth and yield characters. Amer. Int. J. Res. Appl \& Natu. Sci., 13: 9-14.

Sedighe, N. S. and K. Kavoos (2015). Effect of zinc sulfate and iron sulfate fertilizers on some morphological characteristic of Phaseolus vulgaris Bull. Env. Pharmacol. Life Sci. 4 (2):74-78. 
استجابه اللوبيا للرش الورقي بالعناصر الصغري (الزتك والحديد والمنجنيز) وإنعكاس ذلك علي المحصول البذري ومكوناته

\author{
أثرف يحيى إسماعيل ، هاله حسن ابو النور
}

اقسام بحوث الخضر - معهد بحوث البساتين - مركز البحوث الزراعيه - القاهرة.

الملخص العربي

اجريت هذه التجربه الحقليه بمزرعه بحوث الخضر بقها - محافظه القليوبيه التابعه لمعهد بحوث البساتين -

مركز البحوث الزراعيه خلا موسمين صيفين 2014 و 2015 بهدف دراسة ناثير الرش ببعض العناصر الصغري ممثله في الحديد - الزنك و المنجنيز بتركيزى 150 و 200 جزء في المليون سواء منفرده أو مخلوطأ

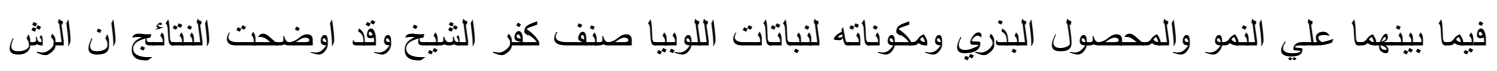
الورقي بمخلوط من العناصر الصغري (الحديد - الزنك والمنجنيز بتركيز 150 جزء في المليون) ادت الي زياده معنويه في كل من صفات النمو والمحصول البذري ومكوناته وكذلك المحتوي الكيميائي لبذور اللوبيا منل البروتين

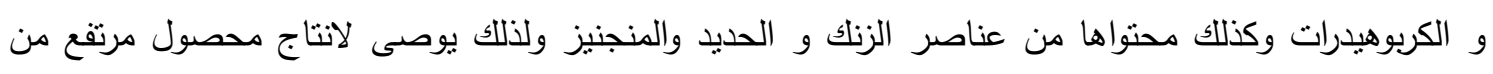

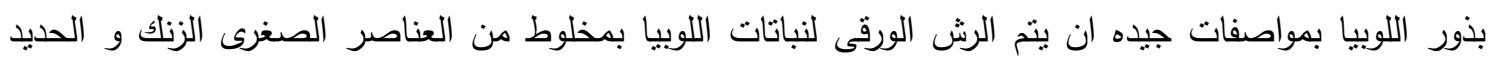

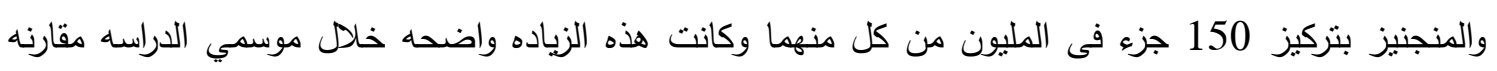

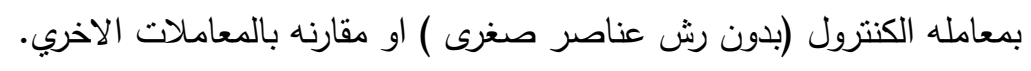

